\title{
PEMBERDAYAAN IBU-IBU KELOMPOK WANITA TANI DAN PKK DI DESA SINDON BOYOLALI MELALUI PENGEMBANGAN PRODUK GREENBOS DAN NUGGET DARI SAYURAN
}

\author{
${ }^{1)}$ Rusdin Rauf, ${ }^{2)}$ Pramudya Kurnia \\ Fakultas Ilmu Kesehatan Universitas Muhammadiyah Surakarta \\ 1) email: rusdin.rauf@ums.ac.id, \\ ${ }^{2)}$ email: Pramudya.Kurnia@ums.ac.id
}

\begin{abstract}
High production of vegetables can result in low prices. Vegetable flour-based food products processing is not only an effort to improve the consumption of vegetables, but also can maintain its economic value, especially during the harvest season. Greenbos and nugget are potential food products developed from vegetables flour. As well as a distinctive flavor, these products also provide an attractive color and good for health. The purpose of the community development activities was to provide skills in Kelompok Wanita Tani and PKK as partners in the Sindon Village Boyolali, in greenbos and nugget production from vegetables flour. The method was used in this activity included the introduction of vegetables flour production. After that, the partners were gave a training in product manufacturing of vegetables flour based. Thus, evaluation step was conducted by asking the partners to create products with developing recipes and creativities. The results indicated that all members of partners have been able to master the skills in manufacture of greenbos and nugget from vegetables flour.
\end{abstract}

Keywords: vegetable flour, greenbos, nugget, Sindon, Boyolali

\section{PENDAHULUAN}

Boyolali merupakan salah satu kabupaten di Jawa Tengah, yang memiliki 19 Kecamatan, salah satunya adalah kecamatan Ngemplak. Kecamatan Ngemplak terletak di sebelah timur dari wilayah kabupaten Boyolali dan lebih dekat dengan wilayah kota Surakarta dan kabupaten Karanganyar. Kecamatan Ngemplak merupakan daerah yang sangat istimewa bagi kabupaten Boyolali karena memiliki fasilitas yang sangat penting, yaitu adanya Bandara Internasional Adi Soemarmo dan embarkasi haji Donohudan, terletak di wilayah Kecamatan Ngemplak. Secara administratif, Kecamatan Ngemplak memiliki 12 desa, salah satunya adalah desa Sindon, yang terletak persis di sebelah utara Bandara Adi Soemarmo (BAPPEDA Kabupaten Boyolali, 2015).
Desa Sindon memiliki jumlah penduduk \pm 5.098 jiwa, dimana lebih dari separuhnya berprofesi sebagai petani. Desa Sindon merupakan sentra produksi sayuran di Kecamatan Ngemplak, yaitu sawi, kangkung dan bayam, dengan luas lahan 48 hektar (BPS Kabupaten Boyolali, 2016). Produksi sayuran desa Sindon cukup melimpah apalagi pada saat musim hujan, tidak kurang dari 5 ton/hari dihasilkan, sehingga harga sayuran seringkali jatuh pada saat produksi yang melimpah ini. Harga normal seikat kangkung dari petani adalah Rp. 400,- s.d 500,-/perikat, dan menjadi Rp. 200,- di saat produksi melimpah.

Kondisi ini menyebabkan petani mengalami kerugian. Keterbatasan pengetahuan petani terhadap kondisi pasar maupun penanganan pasca panen, 
menyebabkan kondisi petani selalu berada pada posisi yang dirugikan. Untuk mengantisipasi kerugian tersebut, diperlukan agar petani memiliki keterampilan mengolah sayuran menjadi produk yang tahan lama dan memiliki nilai ekonomi yang lebih tinggi.

Salah satu upaya yang dilakukan untuk membantu petani adalah melalui program pengabdian masyarakat. Masyarakat, khususnya ibu-ibu kelompok wanita tani dan ibu-ibu PKK, diberikan keterampilan dalam mengolah sayuran menjadi tepung sayuran. Tepung sayuran kemudian dijadikan sebagai intermediate product yang memiliki masa simpan yang lebih lama, dan fleksibel untuk diolah menjadi berbagai produk pangan. Produk pangan yang cukup potensial untuk dikembangkan adalah greenbos dan nugget dari sayuran.

Tujuan dari kegiatan pengabdian masyarakat ini adalah untuk memberikan keterampilan bagi ibu-ibu Kelompok Wanita Tani dan PKK di Desa Sindon Kecamatan Ngemplak Boyolali dalam memanfaatkan sayuran yang diolah menjadi produk pangan greenbos dan nugget.

\section{METODE PELAKSANAAN KEGIATAN}

Kegiatan pengabdian masyarakat di desa Sindon kecamatan Ngemplak Kabupaten Boyolali ini, dibagi menjadi lima tahap, yaitu:

Tahap 1. Sosialisasi pada masyarakat terkait rencana dan program pengabdian masyarakat.

Pada tahap ini, masyarakat diminta untuk membuat tepung sayuran secara mandiri.

Tahap 2. Pelatihan pembuatan greenbos dari tepung sayuran.

Pada tahap ini, peserta dibagi menjadi 3 kelompok. Setiap kelompok menggunakan tepung sayuran yang sama. Nara sumber memberikan materi cara pembuatan greenbos, kemudian setiap kelompok mempraktekkan cara pengolahannya, yang didampingi oleh Nara sumber dan timnya. Setelah selesai waktu yang ditentukan, peserta menyajikan produk olahannya pada Narasumber, selanjutnya dilakukan pengujian sensorik.
Hasil pengujian disampaikan pada peserta sebagai bahan evaluasi.

Tahap 3. Pelatihan pembuatan nugget dari tepung sayuran.

Pada tahap ini, Nara sumber memberikan materi cara pembuatan nugget, kemudian setiap kelompok mempraktekkan cara pengolahannya, yang didampingi oleh Nara sumber dan timnya. Selanjutnya, peserta menyajikan produk olahannya pada Narasumber, untuk dilakukan pengujian sensorik. Hasil pengujian disampaikan pada peserta sebagai bahan evaluasi.

Tahap 4. Evaluasi keterampilan dan kreativitas.

Tahap ini dilakukan untuk mengevaluasi keterampilan dan kemampuan peserta dalam memproduksi greenbos dan nugget sayuran. Peserta juga diberi kesempatan untuk mengembangkan ide-ide kreatifnya dalam mengolah tepung sayuran menjadi produk greenbos dan nugget. Kegiatan dilakukan melalui lomba kreativitas membuat produk greenbos dan nugget. Produk greenbos dan nugget yang dihasilkan, dinilai oleh narasumber secara sensorik.

Tahap 5 Pelatihan pengemasan produk olahan sayuran.

Pada tahap ini, peserta diberikan keterampilan tentang cara mengemas produk greenbos dan nugget dengan kemasan plastik untuk tujuan komersil.

\section{HASIL PELAKSANAAN KEGIATAN}

\section{Sayuran dan Tepung Sayuran}

Sesuai dengan permasalahan yang dihadapi mitra, telah diberikan pelatihan tentang pembuatan tepung sayuran. Berbagai jenis sayuran dapat diolah menjadi tepung sayuran, seperti kangkung, bayam dan sawi. Pada dasarnya, tahap pengolahan tepung sayuran sama untuk setiap jenis sayuran, meskipun ada teknik spesifik untuk karakteristik sayuran tertentu.

Tahap pembuatan tepung yang dipraktekkan yaitu daun sayuran dipisahkan daribatangdengancaradipitongmenggunakan pisau atau gunting. Daun tidak diiris atau dilukai, karena dapat menyebabkan warna 
tepung menjadi gelap. Khusus untuk sawi, pada bagian tengah terdapat jaringan yang tebal. Jaringan tebal dari sawi diiris-iris agar pengeringan cepat. Daun sayuran kemudian dicuci dengan hati-hati agar daun tidak patah atau cacat. Pencucian menggunakan air mengalir. Daun sayuran ditata diatas tampah, kemudian ditutup menggunakan kain hitam. Daun sayuran dikeringkan dibawah sinar matahari. Selanjutnya, sayuran kering diblender kemudian diayak. Makin halus ayakan, semakin baik. Bagian yang tidak lolos ayakan, diblender ulang hingga 2-3 kali. Tepung sayuran dikemas dan diberi

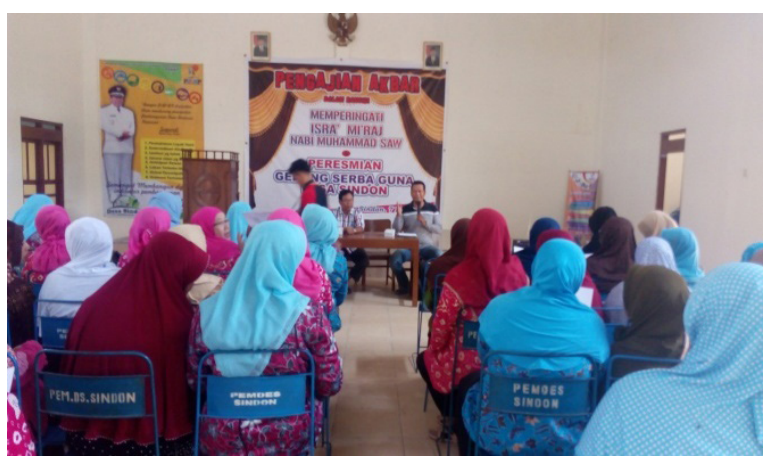

Kegiatan pelatihan label/ditulis: nama tepung sayuran dan tanggal produksi. Tepung sayuran disimpan di tempat/ruang kering. Hindarkan terkena cahaya matahari langsung. Saat tepung sayuran akan digunakan, diambil tepung sayuran yang lebih dulu dibuat.

Salah satu faktor penting yang sangat berpengaruh terhadap kualitas produk pangan olahan adalah ukuran dan keseragaman partikel tepung. Pada pelatihan ini, peserta diberikan pemahaman dan pengenalan penggunaan ayakan terstandar agar diperoleh tepung sayuran dengan keseragaman dan ukuran partikel terstandar, yaitu 80 mesh.

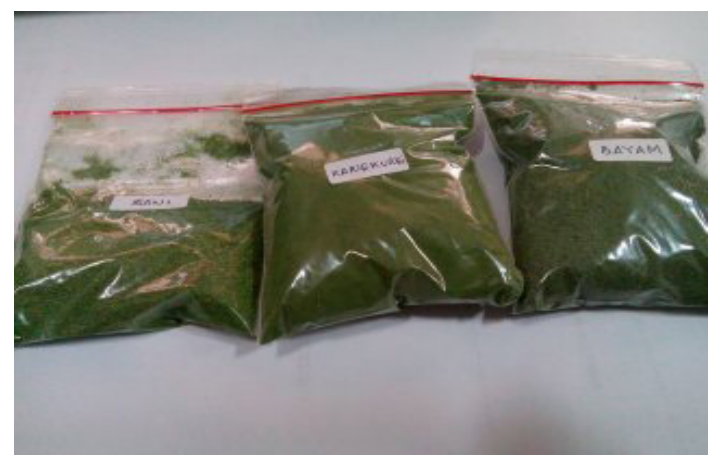

Tepung sayuran

Gambar 1. Kegiatan pelatihan dan produk tepung sayuran (tepung sawi, tepung kangkung dan tepung bayam)

Setelah dilaksanakan pelatihan, mitra diminta untuk memproduksi sendiri tepung sayuran. Hasilnya menunjukkan bahwa semua peserta pelatihan telah dapat memproduksi tepung sayuran dengan hasil yang sangat baik. Beberapa tepung yang diproduksi oleh mitra antara lain dari sawi jepang, kangkung, bayam dan kelor. Tepung sayuran yang telah diproduksi oleh mitra, kemudian dijadikan sebagai bahan baku untuk pelatihan pembuatan berbagai produk jajanan.

Sayuran dapat diperpanjang masa simpannya dengan cara diolah menjadi tepung sayuran. Pengolahan tepung sayuran dapat dilakukan dengan menggunakan teknologi sederhana yang dengan mudah dapat dilakukan oleh masyarakat. Rauf dan Sarbini (2015) menjelaskan bahwa dalam bentuk tepung, bahan pangan selain lebih mudah dalam proses pendistribusian dan perdagangan, juga menjadi produk antara yang sangat fleksibel untuk diolah menjadi beragam produk pangan yang digemari masyarakat, khususnya remaja.

Sayuran merupakan bahan pangan sumber vitamin, mineral dan serat, sehingga sangat baik dikonsumsi untuk kesehatan. Namun, konsumsi sayur oleh masyarakat Indonesia, masih cukup rendah, karena citarasa kurang disukai, terutama generasi muda. Slamet (2011) dan Syahza (2003) menerangkan bahwa dalam bentuk olahan, produk berbahan sayuran akan digemari oleh berbagai lapisan masyarakat termasuk anak-anak dan remaja karena disamping penampilan dan citarasanya yang menarik, produk tersebut juga lebih menyehatkan dibanding produk lainnya yang telah beredar di pasaran. Produk olahan sayuran yang 
sangat potensial dikembangkan adalah biskuit, mie basah, mie instan, greenbos dan nugget.

\section{Produk Olahan Tepung Sayuran}

Pada tahap selanjutnya, mitra diberikan pelatihan tentang pembuatan berbagai produk jajanan dengan penambahan tepung sayuran yang diproduksi sendiri oleh peserta. Produk jajanan yang dipraktekkan dalam pelatihan adalah nugget sayuran dan greenbos (greenies bukan brownies). Pelaksanaan pelatihan dilakukan satu kali untuk setiap jenis produk. Pelatihan dilakukan dengan melakukan praktek pembuatan produk. Peserta dibagi menjadi tiga kelompok. Produk yang dihasilkan dari setiap kelompok dievaluasi secara sensorik oleh narasumber. Selanjutnya narasumber menginformasikan hasil penilaian, berupa kelebihan dan kekurangan produk. Pada pelatihan ini berbagai pertanyaan diajukan oleh peserta terkait upaya pengembangan produk untuk meningkatkan mutu dan variasi citarasa dalam rangka memenuhi permintaan konsumen.

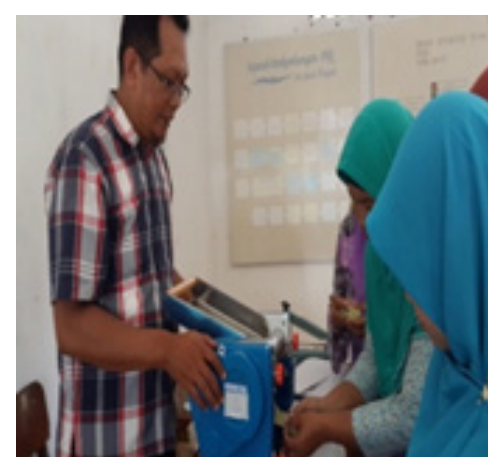

Kegiatan pelatihan olahan produk makanan

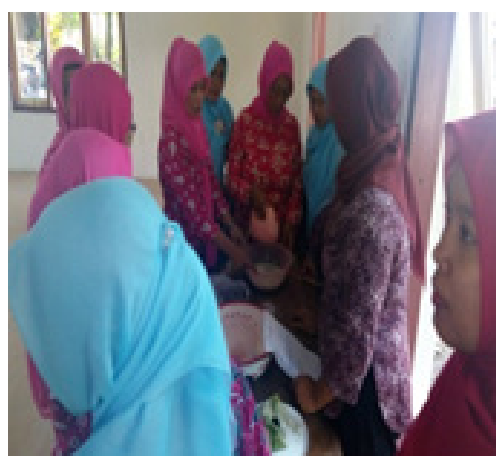

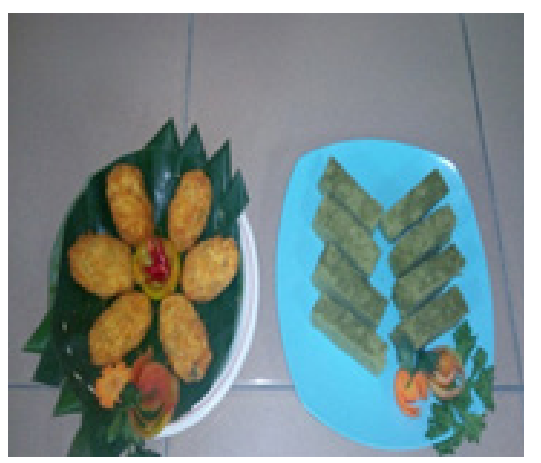

Produk Olahan Makanan

Gambar 2. Kegiatan pelatihan pembuatan produk berbahan tepung sayuran

Tindak lanjut dari pelatihan dan evaluasi tersebut, dilakukan pembinaan lebih lanjut, dengan meminta peserta pelatihan untuk membuat produk pangan seperti yang telah diberikan selama pelatihan. Tujuannya adalah untuk memastikan bahwa mitra dapat membuat produk pangan berbahan tepung sayuran dengan mutu yang baik serta dapat memodifikasi produknya.

\section{Pengemasan Produk}

Mitra diperkenalkan tentang berbagai jeniskemasan plastik serta pelabelankemasan. Penggunaan kemasan plastik diperkenalkan untuk produk basah maupun produk kering. Melalui pelatihan, mitra mempraktekkan teknik melakukan pengemasan.

Mitra telah melakukan proses produksi untuk tujuan komersil, namun belum kontinu, karena pemasaran masih dilakukan secara terbatas yaitu menerima pesanan untuk berbagai kegiatan. Upaya melakukan pendampingan terutama dalam pemasaran masih perlu dilakukan dengan memanfaatkan berbagai media promosi dan pemasaran berbasis internet.

\section{KESIMPULAN DAN SARAN}

\section{Kesimpulan}

Kesimpulan dari pelaksanaan kegiatan PAKOM di Desa Sindon, Boyolali ini adalah: (1) Mitra telah memahami berbagai aspek dalam produksi tepung sayuran dan telah mengaplikasikan proses produksinya. (2) Mitra telah memiliki keterampilan dalam proses produksi nugget dan greenbos berbahan tepung sayuran dan telah melakukan proses produksi untuk tujuan komersil. (3) Mitra telah memahami teknik pengemasan produk pangan olahan tepung sayuran.

\section{Saran}

Berdasarkan perkembangan yang dicapai dalam kegiatan PAKOM ini, beberapa hal yang dapat disarankan, yaitu: (1) Perlu 

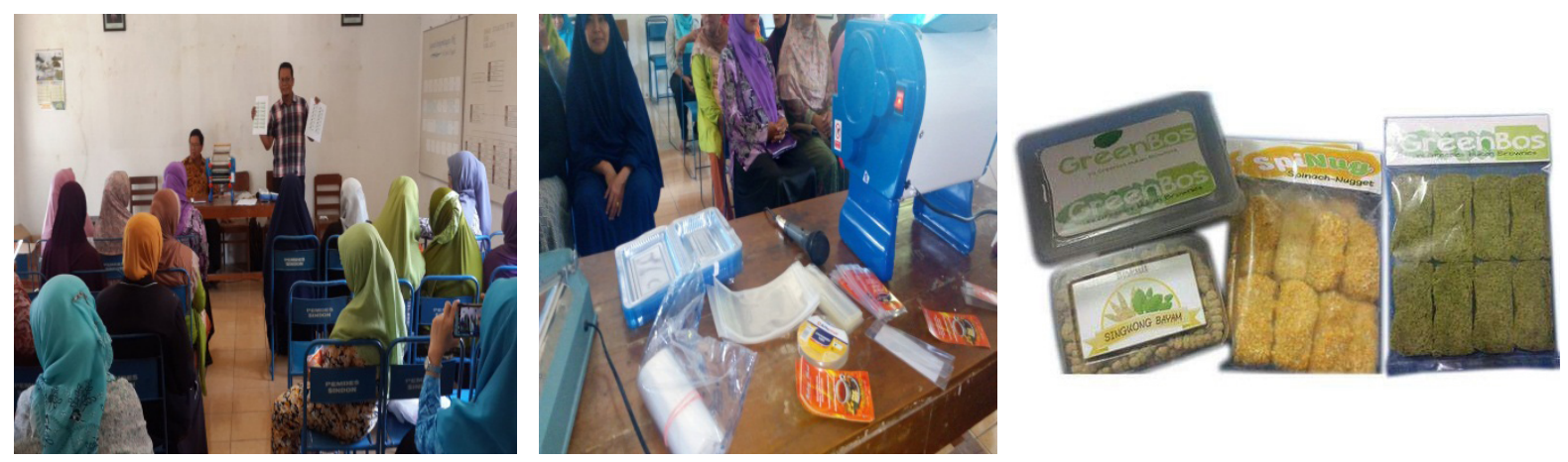

Gambar 3. Pelatihan pengemasan produk

dilakukan sosialisasi di beberapa sekolah terkait keamanan makanan jajanan dan melakukan promosi produk olahan sayuran yang sehat dan aman. (2) Masih diperlukan pendampingan untuk meningkatkan pemasaran, baik secara langsung maupun melalui media online.

\section{UCAPAN TERIMAKASIH}

Ucapan terimakasih disampaikan kepada Lembaga Penelitian dan Pengabdian kepada Masyarakat (LPPM) Universitas Muhammadiyah Surakarta yang telah memberikan dukungan finansial dalam pelaksanaan PAKOM di Desa Sindon.

\section{DAFTAR PUSTAKA}

BAPPEDA Kabupaten Boyolali, 2015. Kabupaten Boyolali dalam Angka tahun 2014. Badan Perencanaan pembangunan Daerah Kabupaten Boyolali.

BPS Kabupaten Boyolali, 2016. Kecamatan Ngemplak dalam Angka. Badan Pusat Statistik Kabupaten Boyolali.

Duncan, K., Chompoothong, N., dan Burnette, R., 2012. Produksi Sayuran di Sepanjang Musim Hujan, ECHO Asia Notes, A Regional Supplement to ECHO Development Notes Issue 13, April 2012, http://c.ymcdn.com/sites/members.echocommunity.org/resource/ collection/2ADC04E9-EE7C-48C0-8DC9-826B93145277/13 Produksi_Sayuran_di Sepanjang_Musim_Hujan_FN2 Tyas_\%281\%29.pdf diakses pada 4 Maret 2015.

Koswara, S., 2009. Teknologi Pengolahan Sayuran dan Buah-Buahan (Teori dan Praktek), eBookPangan.com,http://tekpan.unimus.ac.id/wp-content/uploads/2013/07/TeknologiPengolahan-Sayuran-dan-Buah-buahan-Teori-dan-Praktek.pdf diakses pada 2 Maret 2015.

Ojagh, S. M., Shabanpour, B. dan Jamshidi,A., 2013. The effect of different pre-fried temperatures on physical and chemical characteristics of silver carp fish (Hypophthalmichthys molitrix) Nuggets. World Journal on Fish and Marine Sciences, 5 (4): 414 - 420.

Rauf, R., 2013. Sanitasi Pangan \& HACCP. Penerbit Graha Ilmu, Yogyakarta.

Rauf, R., 2015. Kimia Pangan. Penerbit ANDI, Yogyakarta.

Rauf, R. dan Sarbini, D., 2015. Daya serap air sebagai acuan untuk menentukan volume air dalam pembuatan roti dari campuran tepung terigu dan tepung singkong. AGRITECH, 35 (3): $324-330$.

Rauf, R., Muhtadi, Harismah, K., dan Saifuddin, (2015). Pendampingan pembuatan mie dan biskuit dari tepung sayuran pada kelompok ibu-ibu petani di Desa Sindon Ngemplak Boyolali. The $2^{\text {nd }}$ University Research Colloquium 2015: 277-282. 
p ISSN: 1410-9344, e ISSN: 2549-5631

Rusmana, D., Saefulhadjar, D., (2007), Pengaruh Pengolahan Limbah Sayuran Secara Mekanis Terhadap Kecernaan dan Efisiensi Penggunaan Protein pada Ayam Kampung Super, Penelitian Peneliti Muda, Tidak Dipublikasikan, Universitas Padjajaran Bandung.

Santoso, A., (2011), Serat pangan (dietary fiber) dan manfaatnya bagi kesehatan. Magistra, No. 75 Th. XXIII Maret 2011, 35-40.

Slamet, A., (2011), Fortifikasi tepung wortel dalam pembuatan bubur instan, AGROINTEK, 5 (1): $1-8$.

Syahza, A., (2003), Peluang Pengembangan Agribisnis Sayur-Sayuran di Kabupaten Karimun Riau, Jurnal SAGU, Vol. 2 No. 3, 27-33. 